\title{
Morbidity and mortality in Holstein calves from birth to 145 days of age on a large dairy farm in Brazil
}

\author{
[Morbidade e mortalidade em bezerras da raça Holandesa do nascimento aos 145 dias de vida, \\ em uma grande fazenda produtora de leite no Brasil]

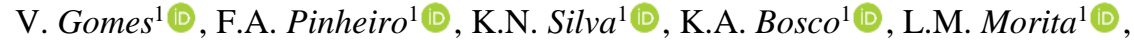 \\ A.H.H. Minervino ${ }^{2}$, K.M. Madureira ${ }^{3}$ (1) \\ ${ }^{1}$ Universidade de São Paulo, Faculdade de Medicina Veterinária e Zootecnia, São Paulo, SP, Brasil
${ }^{2}$ Universidade Federal do Oeste do Pará, Santarém, PA, Brasil
${ }^{3}$ Universidade Federal da Bahia, Escola de Medicina Veterinária e Zootecnia, Salvador, BA, Brasil
}

\begin{abstract}
The present study aimed to investigate the morbidity and mortality associated with the most common diseases during the rearing period of Holstein calves in a high-production dairy farm. The calves $(\mathrm{n}=$ $600)$ were allocated to three groups based on age: G1 (1-7 days, $n=216), G 2$ (30-40 days, $n=188$ ), and G3 (69-85 days, $\mathrm{n}=196)$. They were evaluated over 60 days at eight different times. The morbidity rates were $47.67 \%$ (286/600) for diarrhea, $73.00 \%$ (438/600) for bovine respiratory disease (BRD), and 3.83\% (23/600) for umbilical inflammation (UI). The mortality rate was $2.33 \%(14 / 600)$ for all the animals studied. The morbidity differed in the groups, with higher rates of diarrhea $(78.85 \%, 166 / 216)$ and UI $(6.94 \%, 15 / 216)$ in $\mathrm{G} 1$, and the highest rate of BRD in G3 $(79.59 \%, 156 / 196)$. Diarrhea was associated with the occurrence of BRD in G1 and G2. Even in farms with good management practices, there is high morbidity associated with diarrhea and BRD, with the morbidity rate for diarrhea decreasing and that for BRD increasing as the animals get older. In addition, diarrhea is an important risk factor for BRD, especially in younger animals.
\end{abstract}

Keywords: Bovine respiratory disease, neonatal diarrhea, calf rearing, diseases

\section{RESUMO}

O presente estudo objetivou investigar a morbidade e a mortalidade associadas às doenças mais comuns no período de criação de bezerras da raça Holandesa, em uma fazenda leiteira de alta produção. As bezerras $(n=600)$ foram alocadas em três grupos de acordo com a idade: G1 (1-7 dias, $n=216)$; G2 (30-40 dias, $n=188)$; G3 (69-85 dias, $n=196)$. Os animais foram avaliados durante 60 dias, em oito momentos diferentes. A morbidade foi de 47,67\% (286/600) para diarreia, 73,00\% (438/600) para doença respiratória bovina (DRB) e 3,83\% (23/600) para inflamação umbilical (IU). A taxa de mortalidade foi de 2,33\% (14/600), para o total de animais avaliados. A morbidade foi diferente entre os grupos, com maior frequência de diarreia $(78,85 \%, 166 / 216)$ e IU $(6,94 \%, 15 / 216)$ no $G 1$, sendo a maior ocorrência de DRB no G3 (79,59\%, 156/196). A diarreia foi associada à DRB no G1 e no G2. Mesmo em fazendas com boas práticas de manejo, há alta morbidade por diarreia e DRB, com a taxa de morbidade por diarreia diminuindo e a de DRB aumentando à medida que os animais envelhecem. Além disso, a diarreia é um importante fator de risco para DRB, especialmente em animais mais jovens.

Palavras-chave: doença respiratória bovina, diarreia neonatal, criação de bezerras, doenças

Corresponding author: viviani.gomes@usp.br

Submitted: February 3, 2021. Accepted: May 24, 2021. 


\section{INTRODUCTION}

The rearing phase of dairy calves is important for industrial production, since the calves will be responsible for the supply of milk, replacement of old cows, and genetic improvement of the herd (Santos and Damasceno, 1999). This is a critical period as it contains the animals in the herd most susceptible to the occurrence of diseases, with health status, nutritional management, and animal welfare, factors that directly influence the future production of these animals (Heinrichs and Heinrichs, 2011). In addition, to support a calf from birth to the reproductive period, an expenditure of $15 \%-20 \%$ of the total cost of milk production is required. Thus, it is important to minimize the economic losses caused by morbidity and mortality (Mourits et al., 1997, 1999).

Neonatal diarrhea (ND) and bovine respiratory disease (BRD) are the main causes of morbidity and mortality in the rearing phase of dairy calves, followed by umbilical inflammation (UI) (Windeyer et al., 2014). Digestive and respiratory problems collectively account for almost $80 \%$ of deaths in calves before weaning (Windeyer et al., 2014). Diarrhea, on the other hand, affects $90-100 \%$ of animals aged up to three weeks, which can lead to a mortality rate of approximately $3.5 \%$ during the pre-weaning period (Lagoni et al., 2004; Windeyer et al., 2014). Regarding BRD, in properties monitored by the National Animal Health Monitoring System, $24 \%$ of calf deaths in the pre-weaning phase occur due to respiratory problems (Dairy..., 2014).

There are great variations in the incidence of diseases according to age group and management of the property, and the impact caused by them include a reduction of growth rate, treatment costs, increase in age at first calving, and decrease in future production (Stanton et al., 2012; Windeyer et al., 2014). According to Heinrichs and Heinrichs (2011), animals that became ill or underwent treatment before the age of four months had negative effects on production during the first lactation, including reductions in their milk volume and concentrations of protein and fat. Aghakeshmiri et al. (2017) found that animals with diarrhea had an increase in age at first calving and had decreased milk production during their first lactation. BRD is related to decreased daily weight gain, increased risk of animal culling before the first calving (Adams and Buczinski, 2016), and lower reproductive performance (Teixeira et al., 2017).

Differences in incidence, morbidity, and mortality rates may be related to factors linked to property management, calving, and the environment, such as climate and season, as well as the size of the property (Lundborg et al., 2005; Gulliksen et al., 2009; Windeyer et al., 2014). In Brazil, some studies carried out in different dairy production systems reported diarrhea as the main problem affecting preweaning calves (Lagoni et al., 2004; Hötzel et al., 2014), followed by pneumonia (Santos; Bittar, 2015; Weiller et al., 2020). However, few studies have evaluated the burden of morbidity and mortality from main diseases that affect calves during the pre-weaning period up until weaning and after weaning. Furthermore, in Brazil, most of the studies that evaluated morbidity and mortality were conducted through questionnaires submitted to the owners of the farms, and not with the monitoring of the animals by trained people. The aim of this study was to determine the morbidity and mortality caused by ND, BRD, and UI in Holstein calves from birth to 145 days of age, on a large dairy farm in Brazil, through clinical monitoring of the animals.

\section{MATERIALS AND METHODS}

This research was carried out in conjunction with a randomized clinical trial, which was approved by the Ethics Committee on the Use of Animals (CEUA $\mathrm{n}^{\circ}$ 9010070317) from the Faculty of Veterinary Medicine and Animal Science, University of São Paulo (FMVZ-USP). The study involved 7-month monitoring (May 17th to October 28th, 2017) of 600 Holstein calves, aged between one and 145 days old, from a commercial herd located in the city of Araras SP (latitude $22^{\circ} 21^{\prime} 25^{\prime \prime} \mathrm{S}$, longitude $\left.47^{\circ} 23^{\prime} 03^{\prime \prime} \mathrm{W}\right)$. The farm is one of the largest milk producers in Brazil, having a herd with an average of 1980 lactating cows and producing 39 $\mathrm{kg}$ of milk per cow, reaching close to $80,000 \mathrm{~kg}$ of milk per day, and has good management practices. 
For clinical and disease monitoring, Holstein calves were divided into three experimental groups according to age: group 1 (G1), animals were inserted between one and seven days of life $(\mathrm{n}=216)$; group $2(\mathrm{G} 2)$, from 30 to 40 days $(\mathrm{n}=$ 188 ); and group 3 (G3), from 69 to 85 days ( $\mathrm{n}=$ 196). Clinical evaluations were carried out over 60 days, at eight different times (T0, T1, T3, T5, $\mathrm{T} 7, \mathrm{~T} 15, \mathrm{~T} 30$, and $\mathrm{T} 60$ ), resulting in a final age of 60-67 days in G1 animals, 90-110 days in G2 animals, and 129-145 days in G3 animals. The animals were clinically assessed at all times of the study; this involved assessment of general condition, vital functions, hydration, mucous membranes, and lymph nodes, as well as physical examination of the umbilical region (Dirksen, 1993). Score classification of feces and BRD was also done.

The evaluation for BRD and feces scores was carried out following the procedures for classification by scores described in the Calf Health Scoring Criteria (Poulsen and McGuirk 2009). For BRD, the rectal temperature, nasal discharge, ocular discharge, cough with induction, and head and ear position were evaluated and scored from 0 to 3 according to severity. Calves with a total sum of $\geq 4$ were considered positive for BRD. Stool score was classified by taking into account the fecal consistency, being normal (score 0), pasty/semiformed (score 1), pasty with a large amount of water and/or feces adhered to the perineum (score 2), and liquids with fecal content attached to the perineum (score 3). Animals classified with fecal scores of 2 and 3 were considered positive for ND.

The evaluation of the umbilicus was performed by inspection/palpation, with a score ranging from 0 to 2: normal (score 0), enlargement of the umbilical region, with no systemic sign (score 1), and an increase in the umbilical region, with systemic signs (score 2). Animals classified with scores of 1 and 2 were considered positive for UI.

Briefly, the calves were managed before calving with the cow's care. Pre-calving management consisted of transferring the cows to a maternity freestal paddock with a sand bed and a crossventilation system approximately 60 days before the expected calving, where they received a specific anionic diet in addition to drying of the mammary gland. The vaccination protocol used in this period involved ND (Rotavec $\AA$ Corona, MSD) and environmental mastitis (J-Vac $\AA$, Boehringer Ingelheim), in addition to antimastitic treatment for dry cows (Cepravin $\AA$, MSD) associated with the use of sealants (Teatseal®, Zoetis).

At the time of calving, the cows were transferred to stalls and monitored throughout the period when obstetric intervention was needed. After birth, the calves were separated from their mothers, and the navel was cured with $5 \%$ iodine twice a day until complete mummification and detachment of the external umbilical cord. They were then placed in individual houses.

The cows were sent to a cattle chute for individual hygiene protocols (pre-and postdipping) and colostrum milking. The colostrum was assessed, and only those of medium- to high-quality were used.

Calves were fed with four $\mathrm{L}$ of fresh colostrum containing at least $21 \%$ of the total solid content from their mothers, through a bottle, during the first two hours of life. Fresh colostrum was replaced by frozen colostrum from the property's colostrum bank only when it was identified as being of low quality. From the second feeding up to the 25th day of life, the calves received seven L of waste milk/day and were supplemented with milk replacer (Nattimilk Emax ${ }^{\circledR}$, Auster Nutrição Animal LTDA, Brazil) to achieve a total solid content equal to $14 \%$. This was done in two feedings, increasing to eight liters/day from the 25th day of life until the moment of weaning, which occurred between 69 and 80 days of life. As a mandatory protocol on the farm, all calves received two doses of intranasal vaccine against respiratory disease (Inforce $\AA$, Zoetis), with the first dose administered during the first week of life and the second dose administered between 30 and 40 days of life.

All statistical analyses were performed using Minitab statistical program (Minitab ${ }^{\circledR}$ Statistical Software). The analysis was divided into two stages, with the analysis relating to the total number of calves included in the experiment $(\mathrm{n}=$ 600), where each animal was considered only once. Analyses relating to the total clinical data generated in the evaluation of the different times were then performed $(n=4753)$. Variables 
related to the occurrence of $\mathrm{BRD}, \mathrm{ND}$, and $\mathrm{UI}$ were classified as positive and negative to determine the $\%$ morbidity (number of cases/total animals), and the P-value was calculated using the Chi-square test. The Chisquare test and the Cochran-Mantel-Haenszel test were used to verify the association of diarrhea and UI with the occurrence of BRD.

\section{RESULTS}

The morbidity and mortality rates related to the diseases observed during the study, according to age group, are described in figures $1 \mathrm{~A}$ and $\mathrm{B}$. The mortality rate was $2.33 \%(14 / 600)$ in all animals, $4.17 \%(9 / 216)$ in G1, $1.59 \%$ (3/118) in $\mathrm{G} 2$, and $1.02 \%(2 / 196)$ in G3. BRD was responsible for $57.14 \%(8 / 14)$ of deaths, with $5 / 8$ animals in G1 $(62.5 \%)$ and $3 / 8$ of G2 (37.5\%), followed by BRD associated with diarrhea and UI $(7.14 \%, 1 / 14)$ in G1. The rest of the deaths $(35.71 \%, 5 / 14)$ occurred due to other causes, such as peritonitis $(1 / 5,20.0 \%)$, failure of transfer of passive immunity $(1 / 5,20.0 \%)$, anaphylactoid shock $(1 / 5,20.0 \%)$, and neurological diseases $(2 / 5,40.0 \%)$. There were no cases of mortality due to diarrhea or UI as isolated causes.

The G1 and G2 groups had one of the three diseases assessed at some of the time points studied, and in G3, UI was not observed. For the three diseases, there was a significant difference in the incidence between the groups $(\mathrm{P} \leq 0.05)$, with a higher frequency of diarrhea $(78.85 \%$, $166 / 216)$ and UI $(6.94 \%, 15 / 216)$ in $\mathrm{G} 1$, and a higher occurrence of BRD $(79.59 \%$ 156/196) in G3.
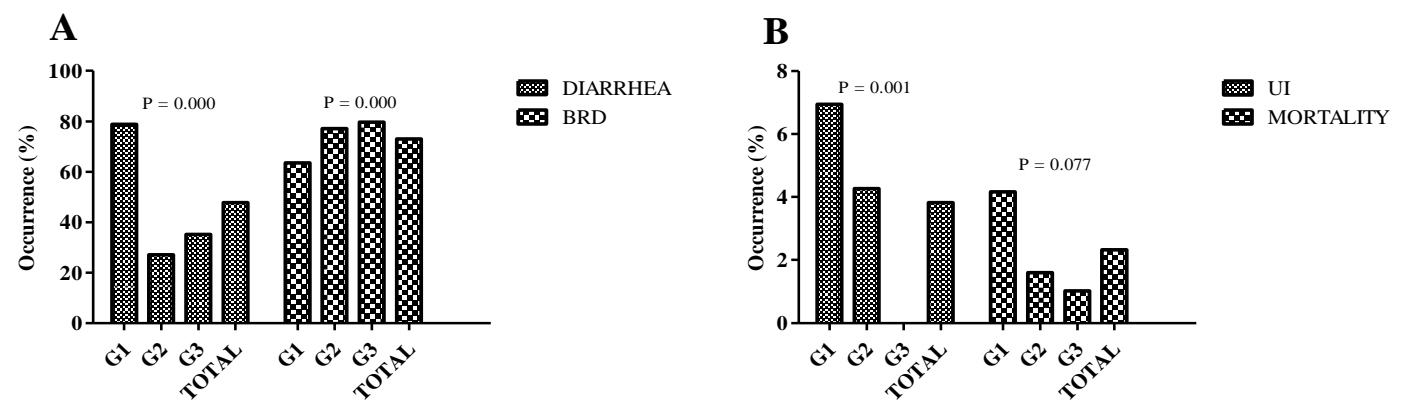

$P$ value obtained from Pearson's Chi-square test, being considered significant when $P \leq 0.05$. G1 - animals from 1 to 67 days old; G2 - animals from 30 to 110 days old; G3 - animals from 69 to 145 days old.

Figure 1. Morbidity and mortality in Holstein calves from birth to 145 days of age. (A) Bovine Respiratory Disease (BRD) and Diarrhea morbidity rates observed during the study period in G1, G2 and G3 groups and in total calves; (B) Umbilical inflammation (UI) morbidity and mortality rates observed during the study period in G1, G2 and G3 groups and in total calves.

Table 1 describes the percentages of the manifestations of the studied diseases, in isolation or association, during all the times that the subjects were evaluated in the study. For the three groups evaluated, mortality rates that occurred at some point in the study influenced total clinical evaluations. Animals evaluated moments before death were also included in the study. Thus, in G1 there were 1708 evaluations, 1489 evaluations in $\mathrm{G} 2$, and 1556 evaluations in G3. Clinical evaluations classified as positive for diarrhea $(15.93 \%, 272 / 1708)$ and UI $(2.99 \%$, $51 / 1708$ ) occurred more frequently in G1. BRB, on the other hand, was recorded more frequently in clinical evaluations of animals in G2 $(22.49 \%$, $335 / 1489$ ). The identification of concomitant diseases in clinical evaluations occurred more frequently in G1, where it was possible to identify the occurrence of the three associated diseases at the same time $(0.35 \%, 6 / 1708)$, in addition to the higher frequency of diarrhea associated with BRD $(4.22 \%, 72 / 1708)$.

Table 2 describes the association between the occurrence of BRD, diarrhea, and UI. In general, diarrhea was associated with BRD in groups 1 and $2(\mathrm{P} \leq 0.05)$, but not in Group $3(\mathrm{P}=0.896)$. 
UI was not associated with BRD in any of the experimental groups.

Table 1. Frequency of Diarrhea, Umbilical inflammation (UI), Bovine Respiratory Disease (BRD) and his associations observed through clinical evaluations in Holstein calves from G1, G2 and G3 groups during the study period

\begin{tabular}{|c|c|c|c|c|c|c|}
\hline \multirow{3}{*}{ Disease } & \multicolumn{6}{|c|}{ Experimental Groups } \\
\hline & \multicolumn{2}{|c|}{ G1 } & \multicolumn{2}{|c|}{$\mathrm{G} 2$} & \multicolumn{2}{|c|}{ G3 } \\
\hline & $(\mathrm{P} / \mathrm{N})$ & $(\%)$ & $(\mathrm{P} / \mathrm{N})$ & $(\%)$ & $(\mathrm{P} / \mathrm{N})$ & $(\%)$ \\
\hline BRD & $(176 / 1708)$ & 10.30 & $(335 / 1489)$ & 22.49 & $(335 / 1556)$ & 21.52 \\
\hline Diarrhea & $(272 / 1708)$ & 15.93 & $(48 / 1489)$ & 3.22 & $(86 / 1556)$ & 5.53 \\
\hline UI & $(51 / 1708)$ & 2.99 & $(22 / 1489)$ & 1.48 & $(6 / 1556)$ & 0.38 \\
\hline UI and Diarrhea & $(12 / 1708)$ & 0.70 & $(0 / 1489)$ & 0.00 & $(0 / 1556)$ & 0.00 \\
\hline UI, Diarrhea and BRD & $(6 / 1708)$ & 0.35 & $(0 / 1489)$ & 0.00 & $(0 / 1556)$ & 0.00 \\
\hline Diarrhea and BRD & $(72 / 1708)$ & 4.22 & $(30 / 1489)$ & 2.01 & $(27 / 1556)$ & 1.74 \\
\hline UI and BRD & $(8 / 1708)$ & 0.47 & $(6 / 1489)$ & 0.40 & $(2 / 1556)$ & 0.13 \\
\hline Total & $(597 / 1708)$ & 34.95 & $(441 / 1489)$ & 29.62 & $(456 / 1556)$ & 29.31 \\
\hline
\end{tabular}

$(\mathrm{P} / \mathrm{N})$ - Number of positives by the total of evaluations. G1 - animals from 1 to 67 days old; G2 - animals from 30 to 110 days old; G3 - animals from 69 to 145 days old.

Table 2. Association of Diarrhea and Umbilical inflammation (UI) with the occurrence of Bovine Respiratory Disease (BRD) in Holstein calves from G1, G2 and G3 groups

\begin{tabular}{|c|c|c|c|c|c|c|c|}
\hline \multirow{3}{*}{ Experimental Group } & \multirow{3}{*}{\multicolumn{2}{|c|}{ Risk Factor }} & \multicolumn{4}{|c|}{ Bovine Respiratory Disease } & \multirow{3}{*}{$\mathrm{P}$-value } \\
\hline & & & \multicolumn{2}{|c|}{ Positive } & \multicolumn{2}{|c|}{ Negative } & \\
\hline & & & $(\mathrm{P} / \mathrm{N})$ & $(\%)$ & $(\mathrm{P} / \mathrm{N})$ & $(\%)$ & \\
\hline \multirow{6}{*}{ G1 } & \multirow{3}{*}{ Diarrhea } & Positive & $(78 / 362)$ & 21,55 & $(284 / 362)$ & 78,45 & \multirow{3}{*}{0.000} \\
\hline & & Negative & $(184 / 1346)$ & 13,67 & $(1162 / 1346)$ & 86,33 & \\
\hline & & Total & $(262 / 1708)$ & 15,34 & $(1446 / 1708)$ & 84,66 & \\
\hline & \multirow{3}{*}{ UI } & Positive & $(14 / 77)$ & 18,18 & $(63 / 77)$ & 81,82 & \multirow{3}{*}{0.479} \\
\hline & & Negative & $(248 / 1631)$ & 15,21 & $(1383 / 1631)$ & 84,79 & \\
\hline & & Total & $(262 / 1708)$ & 15,34 & $(1446 / 1708)$ & 84,66 & \\
\hline \multirow{6}{*}{ G2 } & \multirow{3}{*}{ Diarrhea } & Positive & $(30 / 78)$ & 38,46 & $(48 / 78)$ & 61,54 & \multirow{3}{*}{0.004} \\
\hline & & Negative & $(341 / 1411)$ & 24,17 & $(1070 / 1411)$ & 75,83 & \\
\hline & & Total & $(371 / 1489)$ & 24,92 & $(1118 / 1489)$ & 75,08 & \\
\hline & \multirow{3}{*}{ UI } & Positive & $(06 / 28)$ & 21,43 & $(22 / 28)$ & 78,57 & \multirow{3}{*}{0.667} \\
\hline & & Negative & $(365 / 1461)$ & 24,98 & $(1096 / 1461)$ & 75,02 & \\
\hline & & Total & $(371 / 1489)$ & 24,92 & $(1118 / 1489)$ & 75,08 & \\
\hline \multirow{6}{*}{ G3 } & \multirow{3}{*}{ Diarrhea } & Positive & $(27 / 113)$ & 23,89 & $(86 / 113)$ & 76,11 & \multirow{3}{*}{0.896} \\
\hline & & Negative & $(337 / 1443)$ & 23,35 & $(1106 / 1443)$ & 76,65 & \\
\hline & & Total & $(364 / 1556)$ & 23,39 & $(1192 / 1556)$ & 76,61 & \\
\hline & \multirow{3}{*}{ UI } & Positive & $(2 / 8)$ & 25,00 & $(6 / 8)$ & 75,00 & \multirow{3}{*}{0.914} \\
\hline & & Negative & $(362 / 1548)$ & 23,39 & $(1186 / 1548)$ & 76,61 & \\
\hline & & Total & $(364 / 1556)$ & 23,39 & $(1192 / 1556)$ & 76,61 & \\
\hline
\end{tabular}

P-value obtained from Pearson's Chi-square test, being considered significant when $\mathrm{P} \leq 0.05$. G1 - animals from 1 to 67 days old; G2 - animals from 30 to 110 days old; G3 - animals from 69 to 145 days old.

\section{DISCUSSION}

This study showed the occurrence of ND, BRD, and UI, in addition to the association between these diseases in Holstein calves, from birth to 145 days of life on a large dairy farm in Brazil. In the present study, the total mortality rates in the three experimental groups $(2.33 \%)$ were similar to the findings of Windeyer et al. (2014), who evaluated animals from birth to three months of age $(3.5 \%)$. Other studies have reported higher and varied rates (Swan et al., 2007; Zucali et al., 2013; Cuttance et al., 2017). Here, BRD was the main cause of mortality in 
the calf rearing period, followed by BRD associated with diarrhea and UI. Svensson et al. (2006) also observed the highest mortality from respiratory disease $(59.3 \%)$ in calves between one and 90 days of age, which was similar to the findings of this study $(57.14 \%)$.

According to Windeyer et al. (2014), environmental contamination, management, and stressful social factors may be important causes of mortality, as well as the presence of the agents that cause these diseases. Despite strict sanitary control and efficient colostrum present on the farm, confinement is also a factor that can significantly influence mortality from respiratory diseases in young cattle (Snowder et al., 2006), which may have contributed, in addition to the other factors already mentioned, to the deaths from BRD observed in the current study. The gold standard for mortality rate from birth to 60 days of life in calf rearing is expected to reach a maximum of 5\% (Dairy..., 2013). The highest occurrence of deaths observed in the animals from G1 was $4.71 \%$, which shows that the property on which the study was conducted fits within this pattern. Among the predisposing factors for the highest occurrence of mortality, dystocia, incorrect handling of colostrum, type of accommodation (individual or collective), and hygiene of the facilities (Godden, 2008; Gulliksen et al., 2009) are the most relevant. The fact that the property in question has provisions for obstetric intervention in cases of dystocia, together with its good practices in handling colostrum and initial care for calves, may have been factors leading to the low mortality rate found. In addition, calves were raised in individual housing. According to Machado Neto et al. (2004), individualized calves are more indicated in the pre-weaning period because they have a lower mortality rate.

The occurrence of diarrhea in the total number of animals $(47.67 \%)$ was lower than expected in dairy farms in Brazil, where the prevalence can vary from 53.65 to $100 \%$ (Lagoni et al., 2004). Such variation has been associated with many production systems existing in the country, with high and low production properties and differences in animal management (Santos and Bittar, 2015). In this study, diarrhea morbidity was below the average expected for Brazil; however, the study was carried out on a dairy farm that follows all good practices in raising calves, which include good management of colostrum, care for the healing of the navel, precalving vaccination of cows for ND, and hygiene care of the facilities. As the main risk factors for diarrhea are associated with pre-calving management, failure in pre-calving vaccination protocols for cows, problems in the management of colostrum, and failure in umbilical disinfection (Millemann, 2009), the good management of the property studied led to a lower occurrence of diarrhea when compared to other studies.

The highest frequency of diarrhea occurred in G1 (78.85\%), which is a value slightly above those observed by Novo et al. (2017), who evaluated animals between seven and 14 days of age $(68.9 \%)$. Although the study by Novo et al. (2017) was conducted on the same property as the present study, several factors, such as a different time of year, changes in management, and methods used in clinical evaluations may explain the difference in prevalence rates (Windeyer et al., 2014). Several studies have shown that there is a higher occurrence of diarrhea and gastrointestinal problems in calves during the autumn and winter periods (Río et al., 2007; Lombard et al., 2007; Windeyer et al., 2014). The fact that the present study was conducted between May and October, which is a period that includes autumn and winter, may have been one of the factors that led to a higher rate of diarrhea when compared to the value in the study by Novo et al. (2017) conducted between July and October, which is a period that includes only winter.

The occurrence of diarrhea in G2 $(27.13 \%)$ and G3 $(35.20 \%)$ was similar to the findings by Seppä-lassila et al. (2016), who verified the occurrence of the disease in animals between 15 and 60 days of life $(32,6 \%)$.

As expected, the highest prevalence of diarrhea was observed in G1 animals, since the main causative agents, such as enterotoxigenic Escherichia coli (K99 or F5), Salmonella spp., rotavirus group A, coronavirus, and Cryptosporidium parvum more frequently affect animals under the age of five days to six weeks (Foster and Smith, 2009).

The general prevalence of BRD $(73.00 \%)$ is within expectations for Brazil, where morbidity 
can reach up to $100 \%$ and mortality up to $34.6 \%$ (Assis-Brasil et al., 2013). Weiller et al. (2020) observed morbidity of $49.6 \%$ from respiratory disease, but their study included five distinct dairy farms all located in the state of Rio Grande do Sul and fewer animals when compared to our study. Differences in BRD incidence and morbidity rates may be associated with the geographic region of the study, climate, size, and management of the farm, as well as genetic factors (Gulliksen et al., 2009). In addition to the detection method used, the diagnosis can often be under or overestimated (Buczinski and Pardon, 2020). Another important factor that may have led to the high morbidity rate for BRD in our study is the fact that the farm is one of the largest producers of milk and has a high density of animals. According to Gulliksen et al. (2009), the risk for the occurrence of BRD is greater in large herds, precisely because the animals in these herds tend to be closer to each other, which favors the transmission of pathogens.

In this study, we used the Wisconsin score (Poulsen and McGuirk 2009) for the diagnosis of BRD; however, its international standardization, considering the breeding systems, characteristics of the herd, and the manifestations of the disease diverge from the Brazilian reality. Thus, future studies considering the use of tools with high sensitivity, such as pulmonary ultrasonography, for the validation of the respective scores for Brazil, are necessary. According to Buczinski and Pardon (2020), screening tests, such as clinical scores; combined with a confirmatory test, such as ultrasound or necropsy only in animals who tested positive in the screening test, would increase the diagnostic accuracy of BRD, thus reducing cost and unnecessary use of antimicrobial drugs.

In the United States, the Department of Agriculture reported an incidence of respiratory disease of approximately $20 \%$, with $24 \%$ of deaths in pre-weaning animals and $58.9 \%$ in post-weaning animals (Dairy..., 2014). Studies carried out using questionnaires on other farms in Brazil (Hötzel et al., 2014; Santos and Bittar, 2015) identified a low occurrence of respiratory problems; however, this may be due to the inability of the owners to recognize the signs of disease, with the evaluations carried out by keepers. In our research, diagnosis was made by trained veterinarians according to the Calf Health
Scoring Criteria (Poulsen and McGuirk 2009), which may have led to greater identification of cases.

UI had a general morbidity rate of $3.83 \%$ (23/600). The highest prevalence was observed in G1 $(6.94 \%)$, with values well below those reported in a study by Reis et al. (2009), who found an occurrence of $42.22 \%(95 / 225)$ in calves used for production and aged between one and 90 days of life. These differences probably occurred due to the type of management adopted on the farms, since the first one had good management practices, such as colostrum and navel healing, while in the second study, the animals were raised more extensively, and there was less adoption of management practices. Factors linked to the host (stress, low body weight, and diversity between the studied age groups) can also interfere with these prevalences (Snowder et al., 2006), which can vary from $1.3 \%$ (Svensson et al., 2006) to $30.0 \%$ (Novo et al., 2017).

In the different experimental groups, there were significant differences $(\mathrm{P} \leq 0.05)$ between the morbidity rates; there was a higher prevalence of diarrhea and UI in G1, while morbidity due to BRD was more prevalent in G2 and G3. This demonstrates that diarrhea and UI decrease with age, which is associated with an increase in the prevalence of BRD. Windeyer et al. (2014) found a decrease in the risk of diarrhea and an increased risk of BRD, as the animals were followed up at birth until they reached 3 months of age. BRD is a multifactorial disease involving environmental factors, the host, and the presence of infectious agents (Woolums et al., 2009).

The main agents of BRD include viruses, such as bovine herpesvirus type 1 (BHV-1), bovine viral diarrhea virus (BVDV), Parainfluenza-3 virus (PI3), bovine respiratory syncytial virus (BRSV), coronavirus $(\mathrm{BCoV})$, and bacteria, such as Mannheimia haemolytica, Pasteurella multocida, Histophilus somni, and Mycoplasma bovis (Woolums et al., 2009). However, the presence of etiological agents alone is not sufficient to cause disease (Windeyer et al., 2014). Management is one of the main predisposing factors for the occurrence of BRD, because when done in the wrong way, it generates stress and immune activity, favoring its occurrence (Hilton, 2014). Stressful events, such as weaning, sudden 
feeding changes, removal of individual facilities, and grouping in batches lead to BRD (Coutinho, 2004). In our study, the animals were weaned between 69 and 80 days of life, during which the incidence of BRD was highest. This was likely due to the stress caused by weaning and the formation of many calves.

In the clinical evaluations carried out throughout the study, the occurrence of some of these diseases was observed concurrently in the three experimental groups, and only in G1 did the three diseases occur simultaneously. In addition, there was an association between the occurrence of diarrhea and BRD in groups 1 and $2(\mathrm{P} \leq 0.05)$. Previous reports have demonstrated the importance of diarrhea as a risk factor for the occurrence of BRD. Svensson et al. (2006) performed a study with data from 3081 animals from 122 different herds and ages between 1 and 90 days, where $96 \%$ of calves that had diarrhea before 90 days of age developed BRD. This is probably due to the immunosuppressive role of diarrhea, which favors the occurrence of BRD; or even predisposing factors that are common between the two diseases, such as failure of passive immunity transfer, failure of navel healing, and poor environmental conditions (Perez et al., 1990; Svensson et al., 2006).

Although UI is not associated with the occurrence of BRD in the present study, Windeyer et al. (2014) reported UI as a factor associated with a higher risk of developing BRD. This difference may be associated with the low prevalence of UI in our study, since the procedures were performed for healing and disinfecting the navel properly, in addition to the colostrum procedures. According to these authors, $20 \%$ of BRD cases can be avoided if the colostrum supply is adequate. In our study, diarrhea and BRD morbidity were high in G1 and G2. One of the factors that may have influenced the greater occurrence of these diseases may be associated with the failure of passive immunity transfer. In the present study, the animals received fresh and frozen colostrum, with the latter being offered frozen colostrum only when the immunological quality of the maternal colostrum did not meet the farm's objectives. According to Novo et al. (2017), the clinical signs of diarrhea and umbilical changes are more pronounced in animals with frozen colostrum. The reason is that there are no more maternal cells in frozen colostrum, which are responsible for improving the immune response of newborns (Reber et al., 2008). The use of frozen colostrum may have been one of the determining factors that influenced the prevalence of the causes in the current study.

Knowledge of the profile of diseases and their relationships with each other in intensive production systems is essential for the adoption of strategies that reduce their occurrence, thus favoring the reduction of morbidity and mortality, and consequently improving the profitability of the productive system.

\section{CONCLUSIONS}

Our results confirm that the main diseases that occur in dairy farms are diarrhea, BRD, and UI, even on farms with high production and good management. The cases of diarrhea and UI decrease as the animals get older, while the cases of BRD increase. In addition, there was an association between diarrhea and BRD, especially in younger animals.

\section{ACKNOWLEDGEMENT}

The authors thank Bayer S.A for its financial support.

\section{REFERENCES}

ADAMS, E.A.; BUCZINSKI, S. Short communication: ultrasonographic assessment of lung consolidation post weaning and survival to the first lactation in dairy heifers. J. Dairy Sci., v.99, p.1465-1470, 2016.

AGHAKESHMIRI, F.; AZIZZADEH, M.; FARZANEH, N.; GORJIDOOZ, M. Effects of neonatal diarrhea and other conditions on subsequent productive and reproductive performance of heifer calves. Vet. Res. Commun., v.41, p.107-112, 2017.

ASSIS-BRASIL, N.D.; MARCOLONGOPEREIRA, C.; HINNAH, F.L. et al. Enfermidades diagnosticadas em bezerros da região sul do Rio Grande do sul. Pesqui. Vet. Bras., v.33, p.423-430, 2013.

BUCZINSKI, S.; PARDON, B. Bovine respiratory disease diagnosis. Vet. Clin. North Am. Food Anim. Pract., v.36, p.399-423, 2020. 
COUTINHO, A. S. Manheimiose pneumônica experimentalmente induzida em bezerros pela Mannheimia (Pasteurella) haemolytica Al- cepa D153: achados do exame físico, hemograma e swabs nasal e nasofaringeano. 2004. 186f. Tese (Doutorado em Medicina Veterinária) Universidade Estadual Paulista, Botucatu, SP.

CUTTANCE, E.L.; MASON, W.A.; MCDERMOTT, J. et al. Calf and replacement heifer mortality from birth until weaning in pasture-based dairy herds in New Zealand. $J$. Dairy Sci., v. 100, p.8347-8357, 2017.

DAIRY 2014 health and management practices on U.S. dairy operations NAHMS Dairy. Riverdale Park: USDA, 2014.

DAIRY calf \& heifer association gold standards II: production and performance standards established for Holstein calves, from birth to 6 months of age, across the United States. New Prague: DCHA, 2013. v.1, 2p.

DIRKSEN, G. Sistema digestivo. In: DIRKSEN, G.; GRUNDER, H. D.; STOBER, M.

3.ed. Rosenberger - exame clínico dos bovinos. Rio de Janeiro: Guanabara Koogan,

1993. p.166-228.

FOSTER, D.M.; SMITH, G.W. Pathophysiology of diarrhea in calves. Vet. Clin. North Am. Food Anim. Pract., v.25, p.13-36, 2009

GODDEN, S.M. Colostrum management for dairy calves. Vet. Clin. North Am. Food Anim. Pract., v.24, p.19-39, 2008.

GULLIKSEN, S.; LIE, K.; LOKEN, T.; OSTERAS, O. Calf mortality in Norwegian dairy herds. J. Dairy Sci., v.92, p.2782-2795, 2009.

HEINRICHS, A.J.; HEINRICHS, B.S. A prospective study of calf factors affecting firstlactation and lifetime milk production and age of cows when removed from the herd. J. Dairy Sci., v.94, p.336-341, 2011.

HILTON, W.M. BRD in 2014: where have we been, where are we now, and where do we want to go? Anim. Health Res. Rev., v.15, p.120-122, 2014.
HÖTZEL, M.J.; LONGO, C.; BALCÃO, L.F. et al. A survey of management practices that influence performance and welfare of dairy calves reared in southern Brazil. PLoS One. v.9, p.1-17, 2014.

LANGONI H.; LINHARES A.C.; AVILA F.A. et al. Contribuição ao estudo da etiologia das diarreias em bezerros de aptidão leiteira no Estado de São Paulo, Brasil. Braz. J. Vet. Res. Anim. Sci., v.41, p.313-319, 2004.

LOMBARD, J.E.; GARRY, F.B.; TOMLINSON, S.M.; GARBER, L.P. Impacts of dystocia on health and survival of dairy calves. $J$. Dairy Sci., v.90, p.1751-1760, 2007.

LUNDBORG, G.K.; SVENSSON, E.C.; OLTENACU, P.A. Herd-level risk factors for infectious diseases in Swedish dairy calves aged 0-90 days. Prev. Vet. Med., v.68, p.123-143, 2005.

MACHADO NETO, R.; FARONI, C.E.; PAULETTI, P.; BESSI, R. Levantamento do manejo de bovinos leiteiros recém-nascidos: desempenho e aquisição de proteção passiva. Rev. Bras. Zootec., v.33, p.2323-2329, 2004.

MILLEMANN, Y. Diagnosis of neonatal calf diarrhoea. Rev. Med. Vet., v.160, p.404-409, 2009.

MOURITS, M.; DIJKHUIZEN, A.; HUIRNE, R.B.M.; GALLIGAN, D.T. Technical and economic models to support heifer management decisions: Basic concepts. J. Dairy Sci., v.80, p.1406-1415, 1997.

MOURITS, M.; HUIRNE, C.; DIJKHUIZEN, A.A. et al. Economic optimization of dairy heifer management decisions. Agric. Syst., v.61, p.1731, 1999.

NOVO S.M.F.; COSTA, J.F.R.; BACCILI, C.C. et al. Effect of maternal cells transferred with colostrum on the health of neonate calves. Res. Vet. Sci., v.112, p.97-104, 2017.

PEREZ, E.; NOORDHUIZEN, J.P.T.M.; VAN WUIJKHUISE, L.A.; STASSEN, E.N. Management factors related to calf morbidity and mortality rates. Livest. Prod. Sci., v.25, p.79-93, 1990.

POULSEN, K.P.; MCGUIRK, S.M. Respiratory disease of the bovine neonate. Vet. Clin. North Am. Food Anim. Pract., v.25, p.121-137, 2009. 
REBER, A.J.; DONOVAN, D.C.; GABBARD, J. et al. Transfer of maternal colostral leukocytes promotes development of the neonatal immune system. Vet. Immunol. Immunopathol., v.123, p.186-196, 2008.

REIS, A.D.S.B.; PINHEIRO, C.P.; LOPES, C.T.A. et al. Onfalopatias em bezerros de rebanhos leiteiros no nordeste do estado do Pará. Ciênc. Anim. Bras., v.1, p.29-34, 2009.

RÍO, N.S.; STEWART, S.; RAPNICKI, P.; CHANG, Y.M.; FRICKE, P.M. An observational analysis of twin births, calf sex ratio, and calf mortality in Holstein dairy cattle. J. Dairy Sci., v. 90, p.1255-1264, 2007.

SANTOS, G.; BITTAR, C.M.M. A survey of dairy calf management practices in some producing regions in Brazil. Rev. Bras. Zootec., v.44, p.361-370, 2015.

SANTOS, G.T.; DAMASCENO, J.C. Nutrição e alimentação de bezerras e novilhas. In: SIMPÓSIO MINEIRO DE NUTRIÇÃO DE GADO DE LEITE, 2., Belo Horizonte, 1999. Anais... Belo Horizonte: Escola de Veterinária da UFMG, 1999. p.39-64.

SEPPÄ-LASSILA， L.; SARJOKARI， K.; HOVINEN, M.; SOVERI, T.; NORRING, M. Management factors associated with mortality of dairy calves in Finland: a cross sectional study. Vet. J., v.216, p.164-167, 2016.

SNOWDER, G.D.; VAN VLECK, L.D.; CUNDIFF, L.V.; BENNETT, G.L. Bovine respiratory disease in feedlot cattle: environmental, genetic, and economic factors. $J$. Anim. Sci., v.84, p.1999-2008, 2006.

STANTON, A.L.; KELTON, D.F.; LEBLANC, S.J. et al. The effect of respiratory disease and a preventative antibiotic treatment on growth, survival, age at first calving, and milk production of dairy heifers. J. Dairy Sci., v.95, p.4950-4960, 2012.
SVENSSON, C.; HULTGREN, J.; OLTENACU, P.A. Morbidity in 3-7-month-old dairy calves in south-western Sweden, and risk factors for diarrhoea and respiratory disease. Prev. Vet. Med., v.74, p.162-179, 2006.

SWAN, H.; GODDEN, S.; BEY, R. et al. Passive Transfer of immunoglobulin $\mathrm{g}$ and preweaning health in Holstein calves fed a commercial colostrum replacer. J. Dairy Sci., v.90, p.3857-3866, 2007.

TEIXEIRA, A.G.V.; MCART, J.A.A.; BICALHO, R.C. Thoracic ultrasound assessment of lung consolidation at weaning in Holstein dairy heifers: reproductive performance and survival. J. Dairy Sci., v.100, p.2985-2991, 2017.

WEILLER, M.A.A.; MOREIRA, D.A.; BRAGANÇA, L.F. et al. The occurrence of diseases and their relationship with passive immune transfer in Holstein dairy calves submitted to individual management in southern Brazil. Arq. Bras. Med. Vet. Zootec. v.72, p.1075-1084, 2020.

WINDEYER, M.C.; LEISE, K.E.; GODDEN, S.M. et al. Factors associated with morbidity, mortality, and growth of dairy heifer calves up to 3 months of age. Prev. Vet. Med., v.113, p.231240, 2014.

WOOLUMS, A.R.; AMES, T.R.; BAKER, J.C. The bronchopneumonias (respiratory disease complex of cattle, sheep and goats). In: SMITH, B.P. Large animal internal medicine. 4.ed. St Louis: Elsevier; 2009. p.602-643.

ZUCALI, M.; BAVA, L.; TAMBURINI, A.; GUERCI, M.; SANDRUCCI, A. Management risk factors for calf mortality in intensive Italian dairy farms. Ital. J. Anim. Sci., v.12, p.162-166, 2013. 